\title{
The Latest Research on RT-QuIC Assays-A Literature Review
}

\author{
Thi-Thu-Trang Dong and Katsuya Satoh *(i)
}

\section{check for}

updates

Citation: Dong, T.-T.-T.; Satoh, K The Latest Research on RT-QuIC Assays-A Literature Review. Pathogens 2021, 10, 305. https:// doi.org/10.3390/pathogens10030305

Academic Editor: Lawrence S. Young

Received: 26 January 2021

Accepted: 3 March 2021

Published: 5 March 2021

Publisher's Note: MDPI stays neutral with regard to jurisdictional claims in published maps and institutional affiliations.

Copyright: (c) 2021 by the authors. Licensee MDPI, Basel, Switzerland. This article is an open access article distributed under the terms and conditions of the Creative Commons Attribution (CC BY) license (https:/ / creativecommons.org/licenses/by/ $4.0 /)$.
Department of Locomotive Rehabilitation Science, Nagasaki University Graduate School of Biomedical Sciences, 1-7-1 Sakamoto, Nagasaki 852-8501, Japan; trangneuro@gmail.com

* Correspondence: satoh-prion@nagasaki-u.ac.jp; Tel.: +81-958-197-991

\begin{abstract}
The misfolding of proteins such as the prion protein, $\alpha$-synuclein, and tau represents a key initiating event for pathogenesis of most common neurodegenerative disorders, and its presence correlates with infectivity. To date, the diagnosis of these disorders mainly relied on the recognition of clinical symptoms when neurodegeneration was already at an advanced phase. In recent years, several efforts have been made to develop new diagnostic tools for the early diagnosis of prion diseases. The real-time quaking-induced conversion (RT-QuIC) assay, an in vitro assay that can indirectly detect very low amounts of $\mathrm{PrP}^{\mathrm{Sc}}$ aggregates, has provided a very promising tool to improve the early diagnosis of human prion diseases. Over the decade since RT-QuIC was introduced, the diagnosis of not only prion diseases but also synucleinopathies and tauopathies has greatly improved. Therefore, in our study, we summarize the current trends and knowledge of RT-QuIC assays, as well as discuss the diagnosis of neurodegenerative diseases using RT-QuIC assays, which have been updated in recent years.
\end{abstract}

Keywords: RT-QuIC assay; prion diseases; diagnosis; synucleinopathy; tauopathy

\section{Introduction}

Neurodegenerative diseases are characterized by the accumulation of disease-related misfolded proteins. Protein misfolding diseases such as prion diseases, Alzheimer's disease (AD), Parkinson's disease (PD), and related misfolded prion protein (PrP), tauopathies, and synucleinopathies represent a major disease burden on society.

Prion diseases, also known as transmissible spongiform encephalopathies (TSEs), are a group of progressive neurodegenerative disorders. Human prion diseases (HBD) include Creutzfeldt-Jakob disease (CJD), fatal insomnia, Gerstmann-Sträussler-Scheinker syndrome, kuru, and variably protease-sensitive prionopath. The hallmark event in prion disorders associated with the deposition of misfolded forms of the prion protein $\left(\mathrm{PrP}^{\mathrm{Sc}}\right)$. It is accepted that $\mathrm{PrP}^{\mathrm{Sc}}$ formation is the key initiating event in prion disease pathogenesis. As such, $\mathrm{PrPS}^{\mathrm{Sc}}$ is also the most widely used diagnostic surrogate marker for affected individuals and animals.

Lewy bodies and Lewy neurites were defined as pathologic hallmarks of Parkinson's disease over a century ago. For 20 years, $\alpha$-synuclein was found to be the primary component of these inclusions. Emerging evidence suggests that $\alpha$-synuclein pathology propagates across interconnected networks throughout the nervous system in a prion-like manner [1].

Among dementias, AD is the most common, with a worldwide prevalence of approximately 35 million people in 2010 [2,3], increasing to 50 million people in 2020 [4]. Total payments in 2020 for health care, long-term care and hospice services for people age 65 and older with dementia are estimated to be \$305 billion [5]. AD is commonly thought to be a secondary tauopathy, and it has a pathogenic mechanism similar to that of prion disease [6]. The key neuropathological feature is the accumulation of tau proteins in the form of self-seeding filaments or sub-filamentous deposits [7]. 
Accurate diagnosis of neurodegenerative diseases is difficult when the patient is still alive, especially at the preclinical stage. Currently, there is no specific treatment, especially the late stage of the disease, but if the disease is detected in an early stage, we will have appropriate supportive treatment methods. One of the amplification techniques is real-time quaking-induced conversion (RT-QuIC) assays which can detect a small of prion seeding activity to exponentially amplify from various biopsies with high sensitivity and specificity.

After more than a decade of the advent and development of the RT-QuIC assays [8,9], it has become a useful tool in the laboratory to aid in the clinical diagnosing of neurodegenerative disorders. To date, RT-QuIC assays have been developing to detect protein seeding activity for prion diseases in animals as well as in humans, $\alpha$-synuclein in the synucleinopathies such as Parkinson disease (PD), multiple system atrophy (MSA), dementia with Lewy bodies (DLB) as well as tau aggregation in Alzheimer's disease (AD), chronic trauma to encephalopathy (CTE), Pick disease (PiD).

In our review, we summarize the trends in the development of RT-QuIC assays in recent years, applying RT-QuIC assays not only for the diagnosis of prion disease but also for other neurodegenerative diseases.

\section{The Advantages of RT-QuIC Assays}

Resistance to proteinase $\mathrm{K}(\mathrm{PK})$ digestion is considered a definition of the transmissible isoform of the prion protein $\left(\mathrm{PrP}^{\mathrm{Sc}}\right)$. Thus, the gold standard of diagnosis for prion disease is detected proteinase $\mathrm{K}$-resistant prion protein $\left(\mathrm{PrP}^{\mathrm{Sc}}\right)$. Like amyloid fibers found in Alzheimer's and other amyloid-related disorders or tau aggregation in tauopathies, $\operatorname{PrP}^{\mathrm{Sc}}$ is a variable polymer that can aggregate large fiber. The immune assay cannot distinguish between $\operatorname{PrP}$ and $\operatorname{PrP}^{\mathrm{Sc}}$ because the distinguishing antibodies are not available. Western blotting (WB) can provide valuable information about the biochemical properties of $\mathrm{PrP}^{\mathrm{Sc}}$, but its detection range is narrow and unsuitable for evaluating the decontamination of prion seeds [10]. For the evaluation of prion decontamination, bioassays are often used, but it takes at least 1 year to quantify infectivity. Similarly, quantitation of infectivity of tissue from a patient with human prion disease can also be achieved by animal bioassays using humanized mice [11,12]; however, these mice have different susceptibilities to human prion strains $[13,14]$, and the assays are still highly time-consuming and costly.

The protein misfolding cyclic amplification assay (PMCA) and RT-QuIC are the two most commonly used $\mathrm{PrP}^{\mathrm{Sc}}$ amplification techniques. Although these two methods have the same basic methodology, they also have differences in their amplification and detection.

PMCA was first described in 2001 [15], in which brain homogenates [16] or cell extracts $[17,18]$ were the source of $\operatorname{PrP}^{\mathrm{C}}$. These methods could successfully diagnose variant Creutzfeldt-Jakob disease (vCJD) using samples from the brain and peripheral tissues such as the spleen and tonsil [19] and biological fluids such as blood [20] and urine [21]. PMCA can be applied in many fields and has a great tool of great significance for researching and diagnosing. This technique is used to understand the biology of unique prion, to detect ultrasensitive prion, and to screen for molecules that interfere with the formation of prion. Furthermore, the prions produced by PMCA can be infected in animals of various species of wild-type. This was supported by the fact that the agent of infecting in TSEs is composed exclusively of protein. Previous studies have also shown the infection material was created by PMCA using brain extracts, cell lysates, high purity $\operatorname{Pr} \mathrm{P}^{\mathrm{C}}$, and even recombinant PrP produced in bacteria [22].

However, the PMCA method only detects the prion seeding activity in the variant in CJD. About 10 years later, a new technique was introduced, the "quaking-induced conversion" (QuIC), which improves the speed and practicality by using recombinant bacterial-expressed $\mathrm{PrPC}(\mathrm{rPrPc})$ and by replacing shake for sonication [9]. Moreover, although RT-QuIC is as sensitive as PMCA in the detection of as little as $1 \mathrm{fg} \mathrm{PrP}{ }^{S c}$ in the brains of sporadic CJD (sCJD) patients [9,23], PMCA requires brain homogenate, the sonication setup is much more difficult and expensive to maintain, and it needs PK digestion of samples and Western blotting for the detection of resistant PrP. These drawbacks make this 
technique highly unsuitable for the diagnosis of TSEs in hospitals or other medical centers. In addition, the RT-QuIC reaction products are not contagious and therefore do not require specialized containment laboratories. Finally, RT-QuIC, besides being low-cost and a multiwall Thioflavin T (ThT) detection form, is better adapted for use as a high-throughput diagnostic assay than PMCA.

\section{The Development of RT-QuIC Assays and Future}

RT-QuIC detects limited amounts of abnormal proteins. It is highly sensitive and specific in various specimens in the central and peripheral nervous systems but is not successful in samples containing blood, including whole blood, blood plasma, or blood-contaminated tissues. Previous studies have suggested that red blood cells in the Cerebrospinal fluid (CSF) sample inhibit the RT-QuIC response [24,25]. A cut-off value of $<1250 \times 106 / \mathrm{L}$ has been recommended [25]. In addition, RT-QuIC has one of the diagnostic criteria sCJD. It is especially valuable in genetic diseases such as GSS and FFI that other CSF tests are negative. However, it has been inhibited in vCJD.

Therefore, an adaptation of RT-QuIC, called e-QuIC, was developed [26]. The study showed that the eQuIC assay can detect up to $10^{14}$-fold dilutions and contains less than $\sim 1$ ag of $\mathrm{PrP}^{\mathrm{Res}}$ vCJD brain homogenates in human plasma, so it was around $10^{4}$ times more sensitive than in the previous study. However, the assay was difficult to standardize and less reproducible than the standard RT-QuIC (given that eQuIC is significantly more sensitive than the RT-QuIC).

Although there have been significant advances in recent years, the sensitivity and speed of first-generation RT-QuIC assays need to improve. One major advance has been developing a second-generation RT-QuIC assay using the N-terminally truncated Syrian hamster $\mathrm{rPrP}$ (SHarPrP (90-231)), comprising 0.002\% sodium dodecyl sulfate (SDS) in the buffer solution and using a reaction temperature increased to $55^{\circ} \mathrm{C}$ [27]. The initial evaluation of the IQ-CSF assay indicated greater analytical and diagnostic sensitivity and markedly shorter testing times [27-30]. Given the huge diagnostic and analytic potential of this technique, future studies should aim to develop a type-specific RT-QuIC to discriminate the molecular subtypes of sCJD cases in vitro to further advance epidemiologic surveillance of sCJD. Although there are many advantages of RT-QuIC, it is clear that this still has certain limitations. Firstly, for RT-QuIC, the recombinant substrate is very important. Therefore, the substrate needs to be standardized and manufactured on a large scale. Second, RT-QuIC has been successful in CSF as well as peripheral tissues. In the near future, there should be more studies on tissues with minimal intervention and that can be checked many times without affecting the patient. Since, as we know, RT-QuIC helps to diagnose at an early stage, minimal intervention therapy is of utmost importance. Thirdly, in prion diseases, RT-QuIC is a part of diagnostic standards. In the future, we should establish RT-QuIC assay as a diagnostic criterion in synucleinopathies and tauopathies.

\section{RT-QuIC in Degenerative Neurological Diseases}

Neurodegenerative diseases are complex, multifactorial, and heterogeneous diseases that are identified by the accumulation of misfolded proteins in the brain. Many neurodegenerative diseases are associated with the accumulation of specific misfolded proteins.

\subsection{Human Prion Disease}

RT-QuIC was first successful in the diagnosis of human prion disease. It is highly accurate in identifying misfolded forms of prion proteins from the CSF of patients with CJD and has already been included in the diagnostic criteria of sporadic CJD, the most common human prion disease (Table 1). The largest study analyzed CSF of 174 patients with gTSEs for 14-3-3, tau protein, S100b, and neuron-specific enolase (NSE). Biomarkers were found positive in $81 \%$ of gCJD and $69 \%$ in gTSE, while most of the GSS and FFI patients were negative for 14-3-3 and t-tau [31]. A study in 56 CSF samples including 20 cases of GSS with P102L mutation, 12 cases of fatal familial insomnia (FFI), and 24 cases of genetic CJD 
(gCJD) detected prion protein in CSF samples by RT-QUIC. Western blotting was used to analyze 14-3-3 protein, and t-tau protein was measured using an ELISA. They found the sensitivities of CSF RT-QUIC 78\%GSS, 100\% FFI, and 87\% gCJD E200K, and 100\% V203I, and all samples had the specific was $100 \%$. Furthermore, the sensitivities of biomarkers were lowered: $11 \%$ in GSS, $0 \%$ in FFI, and 73\% in gCJD E200K 67\% in V203I [32].

Using these first-generation assays, RT-QuIC was shown to have a sensitivity of $77-89 \%$ and a specificity around $100 \%$ [9,33-36]. The specificity of first-generation RT-QuIC assays is close to $100 \%$ and is significantly better than that of surrogate markers such as CSF 14-3-3 or tau protein [34].

The presence of PrPSc in olfactory mucosa $(\mathrm{OM})$ has been mentioned by many previous studies. Table 1 shows that there are successful studies using RT-QuIC to detect prion seeding activity in OM $[28,35]$. One study showed that RT-QuIC response in OM tissue is faster than CSF, with a $97 \%$ sensitivity and a $100 \%$ specificity [35]. Another study performed RT-QuIC on CSF and OM samples from 86 patients. The results showed that the sensitivity was $86 \%$ for CSF and $97 \%$ for OM, and the specificity was $100 \%$ [28].

Table 1. Real-time quaking-induced conversion (RT-QuIC) for prion disease.

\begin{tabular}{|c|c|c|c|c|c|c|}
\hline & Number & $\begin{array}{l}\text { Number } \\
\text { (Controls) }\end{array}$ & Sensitivity & Specificity & Samples & Reference \\
\hline definite cases of sCJD & 34 & 165 & 85 & 100 & CSF & [9] \\
\hline definite cases of sCJD & 123 & 103 & 89 & 99 & CSF & [33] \\
\hline genetic prion disease & 56 & 50 & 83 & 100 & CSF & {$[32]$} \\
\hline \multirow{2}{*}{$\begin{array}{l}\text { definite and probable } \\
\text { cases of sCJD }\end{array}$} & 15 & \multirow{2}{*}{43} & 77 & 100 & CSF & \multirow{2}{*}[35]{} \\
\hline & 13 & & 97 & 100 & $\mathrm{OM}$ & \\
\hline definite cases of sCJD & 10 & 1 & FG: 91 SG: 96 & 100 & CSF & {$[27]$} \\
\hline $\begin{array}{c}\text { definite and probable } \\
\text { cases of sCJD }\end{array}$ & 43 & 100 & 77 & 100 & $\mathrm{CSF}$ & {$[36]$} \\
\hline definite cases of sCJD & 81 & 64 & FG: 69 SG:94 & 100 & Skin samples & [29] \\
\hline $\begin{array}{c}\text { definite and probable } \\
\text { cases of sCJD }\end{array}$ & 276 & \multirow{3}{*}{915} & 81 & \multirow{3}{*}{94} & \multirow{3}{*}{ CSF } & \multirow{3}{*}[34]{} \\
\hline genetic prion diseases & 17 & & 91 & & & \\
\hline $\begin{array}{c}\text { variable } \\
\text { protease-sensitive } \\
\text { prionopathy }\end{array}$ & 1 & & 0 & & & \\
\hline definite cases of sCJD & 12 & 15 & 100 & 100 & Skin & [37] \\
\hline \multirow{2}{*}{ sCJD } & 10 & \multirow{2}{*}{17} & SG: 97 & 100 & $\mathrm{OM}$ & \multirow{2}{*}[28]{} \\
\hline & 12 & & FG: 72 SG: 86 & 100 & CSF & \\
\hline definite cases of sCJD & 174 & 82 & SG: $92-95 \%$ & $98.5-100$ & CSF & [24] \\
\hline \multirow{2}{*}{ definite cases of sCJD } & 11 & 6 & 100 & 100 & Eyes & {$[38]$} \\
\hline & 65 & 118 & 97 & 99 & CSF & [39] \\
\hline definite cases of sCJD & 12 & 2 & 100 & 100 & $\begin{array}{l}\text { Peripheral } \\
\text { nerve }\end{array}$ & {$[40]$} \\
\hline sCJD & 4 & 10 & 100 & 100 & $\begin{array}{l}\text { Digestive } \\
\text { organs }\end{array}$ & {$[41]$} \\
\hline all CJD patients & 32 & 37 & На23-231: 68.6 & 100 & $\begin{array}{l}\text { Skin punch } \\
\text { biopsies }\end{array}$ & {$[42]$} \\
\hline all CJD patients & 102 & 80 & 96 & 100 & $\mathrm{CSF}$ and $\mathrm{OM}$ & [43] \\
\hline
\end{tabular}


A previous study showed that second-generation RT-QuIC helped to increase the diagnositic sensitivity and speed. These results were confirmed in a large study [29], which showed that the second-generation RT-QuIC assay had better reproducibility. The RTQuIC assay detected the prion seeding activity in skin samples of SCJD with a sensitivity of $69 \%$ in first-generation RT-QuIC but higher in second-generation RT-QuIC at 94\%. Another study showed that the sensitivity of RT-QuIC assay in CSF was 72\% for first-generation RTQuIC and 86\% for second-generation RT-QuIC. Moreover, RT-QuIC was also successful for diagnosis using other samples such as peripheral nerves [40] and digestive organs, with the $\mathrm{SD}_{50}$ of digestive tissues reaching $>10^{6-8} / \mathrm{g}$ [41].

\subsection{Synucleinopathies}

PD, multiple system atrophy (MSA), dementia with Lewy bodies (DLB), or Lewy body dementia, are synucleinopathies caused by the abnormal accumulation of protein aggregates called $\alpha$-synuclein in the brain. Outside prion RT-QuIC assays, $\alpha$-synuclein RTQuIC is the most developed RT-QuIC ( $\alpha$-synuclein RT-QuIC) seed amplification platform to aid in premortem diagnosis, largely using CSF specimens.

Despite being developed in the last five years, $\alpha$ Syn RT-QuIC assays have been adapted for a range of diagnostically relevant human biospecimens, including the brain and CSF, olfactory mucosa, submandibular gland, and skin. (Table 2)

It has previously been shown that $\alpha$-synuclein can be detected in the brain and biological fluids such as CSF and serum [44-55].

Table 2. Real-time quaking-induced conversion (RT-QuIC) for the synucleinopathy.

\begin{tabular}{|c|c|c|c|c|c|c|}
\hline Disease & Sample & Number & $\begin{array}{l}\text { Number } \\
\text { (Controls) }\end{array}$ & Sensitivity & Specificity & Reference \\
\hline \multirow{3}{*}{ DLB and PD } & Brain and CSF & 12 & 20 & 92 & 100 & \multirow{3}{*}{ [44] } \\
\hline & \multirow{2}{*}{ CSF } & 17 & \multirow{2}{*}{15} & 65 & \multirow{2}{*}{100} & \\
\hline & & 20 & & 95 & & \\
\hline PD & \multirow{3}{*}{ Brain and CSF } & 76 & \multirow{3}{*}{ ND } & 88.5 & \multirow{3}{*}{94} & \multirow{3}{*}{ [45] } \\
\hline DLB & & 40 & & 100 & & \\
\hline MSA & & 10 & & 89 & & \\
\hline MSA and PD & Brain & 7 & 2 & 100 & 100 & [46] \\
\hline DLB & \multirow{2}{*}{$\begin{array}{l}\text { DLB brain } \\
\text { tissues }\end{array}$} & 17 & \multirow{2}{*}{28} & 94 & \multirow{2}{*}{100} & \multirow{2}{*}{ [47] } \\
\hline $\mathrm{PD}$ & & 12 & & 92 & & \\
\hline PB, MSA & \multirow{2}{*}{$\mathrm{OM}$} & 18 & \multirow{2}{*}{18} & 81.8 & \multirow{2}{*}{84.4} & \multirow{2}{*}{ [48] } \\
\hline CBD, PSP & & 11 & & 16.7 & & \\
\hline DLB & \multirow{2}{*}{ CSF } & 29 & \multirow{2}{*}{49} & 93 & 96 & \multirow{2}{*}{ [49] } \\
\hline MSA & & 1 & & 100 & 100 & \\
\hline $\begin{array}{l}\text { PD, incidental Lewy } \\
\text { body }\end{array}$ & $\begin{array}{l}\text { Submandibular } \\
\text { gland tissues } \\
\text { (FFPE) }\end{array}$ & 15 & 11 & 100 & 100 & [50] \\
\hline LB & \multirow{5}{*}{ CSF } & 21 & \multirow{5}{*}{101} & 95 & \multirow{5}{*}{$84-98$} & \multirow{5}{*}{ [54] } \\
\hline DLB & & 7 & & 94 & & \\
\hline $\mathrm{PD}$ & & 34 & & 97 & & \\
\hline iRBD & & 28 & & 93 & & \\
\hline PAF & & 18 & & 100 & & \\
\hline $\begin{array}{c}\text { PD and other } \\
\text { synucleinopathies. }\end{array}$ & Skin & 57 & 73 & 93-94 & $93-98$ & [56] \\
\hline
\end{tabular}


The first successful use of $\alpha$-syn RT-QuIC was applied to detect $\alpha$-synuclein aggregation in the brain and CSF from dementia with LB and PD patients. The results gave the sensitivities of $92 \%$ and $95 \%$, with an overall specificity of $100 \%$. Patients with tauopathies showed negative results. In particular, they found that three iRBD patients also had a positive RT-QuIC response, suggesting that the method could be used as an early diagnostic of synucleinopathy [44].

A comparably more rapid $\alpha$-syn RT-QuIC was developed, which demonstrated assay times of 1-2 days [45] compared to the 5-13 days shown in a previous study. The study assay also demonstrated $93 \%$ sensitivity and 100\% specificity with blinded analysis of 29 synucleinopathy cases (12 PD and 17 DLB) and controls, including AD [47].

RT-QuIC assay application to the largest cohort of CSF samples has been examined. The method accurately detected $\alpha$-synuclein seeding activity, including DLB, PD, iRBD, and PAF, with a sensitivity of $95.3 \%$. In contrast, in samples of MSA patients, the assays gave no $\alpha$-synuclein seeding activity, showing that MSA and LBD are associated with different conformational strains of $\alpha$-synuclein. The study also showed $98 \%$ specificity in a neuropathological cohort of 101 cases lacking LB pathology [54].

A recent study applied the RT-QuIC assays to detect CSF $\alpha$-synuclein with the isolated rapid-eye-movement sleep behavior disorder. With 52 isolate REM sleep behavior disorder (iRBD) and 9 controls, the results showed that the sensitivity was $90 \%$ and the specificity was 78\%. During follow-up, $32(61.5 \%)$ patients were diagnosed with PD or DLB $3.4 \pm 2.6$ years after LP, and 31 (96.9\%) of these were positive for CSF $\alpha$-synuclein in the RT-QuIC, while none of the controls developed synucleinopathy [55].

Some studies using the RT-QuIC assays to detect $\alpha$-syn on peripheral tissues $[48,50,56,57]$. With the $\alpha$-synuclein in brushes of OM, $\alpha$-synuclein RT-QuIC showed $55.5 \%$ and $81.8 \%$, positive in PD and MSA, respectively. In contrast, only $16.7 \%$ were positive in CBD and PSP. Finally, the assay showed $84.4 \%$ specificity. The most recent research has been successful in detecting phosphorylated $\alpha$-synuclein (P $\alpha$ Syn) seeding activity in the skin by RT-QuIC [56,57]. RT-QuIC analysis of the $\alpha$ SynP seeding activity in autopsy abdominal skin samples revealed a 93-94\% sensitivity and a 93-98\% specificity in synucleinopathies (PD, DLB, and MSA) [56].

\subsection{Tauopathies}

Diseases involving tau pathology include those with preferential aggregation of 3 microtubule binding-repeat (3R), 4-repeat (4R), or both $3 R$ and $4 R(3 R / 4 R)$ tau isoforms. The predominant $3 R$ tau isoforms can be seen in In Pick disease (PiD). The $3 R$ and $4 R$ isoforms are deposited in AD. 4R tauopathies include corticobasal degeneration (CBD), progressive supranuclear palsy (PSP), globular glial tauopathy (GGT), and argyrophilic grain disease (AGD).

It has previously been shown that the A $\beta$ and tau PMCA/RT-QuIC may work in diagnosing $\mathrm{AD}$ by distinguising between $\mathrm{AD}$ patients and other neurodegenerative disorders or controls by protein misfolding cyclic amplification assay (Ab-PMCA) with more than $90 \%$ of sensitivity and specificity using cerebrospinal fluid [58]. AD RT-QuIC assay can detect tau filaments in AD and chronic traumatic encephalopathy (CTE) from the brain tissue. Moreover, $\mathrm{A} \beta$ misfolding and aggregation is thought to precede tau misfolding and aggregation, although previous studies have shown amazing results in detecting AD even at the preclinical stage by biomarkers (CSF A $\beta 42 / 40$, t-tau, and p181-tau) [59]. However, the most useful of the tau-RT-QuIC will be the differential diagnoses of primary tauopathies (Table 3). 
Table 3. Real-time quaking-induced conversion (RT-QuIC) for the tauopathies.

\begin{tabular}{|c|c|c|c|}
\hline Sample & Number and Disease & Result & Reference \\
\hline & $\begin{array}{l}8 \text { cases: } \mathrm{PiD} \\
13 \text { cases: } \mathrm{AD}\end{array}$ & \multirow{2}{*}{$\begin{array}{l}\text { Tau RT-QuIC that can detect tau seeds in } 2 \mu \mathrm{l} \\
\text { aliquots of PiD brain dilutions down to } 10^{-7}-10^{-9} \text {. } \\
\text { PiD seeding activities were } 10^{2} \text {-fold higher in frontal } \\
\text { and temporal lobes compared to cerebellar cortex. } \\
\text { Strikingly, this test was } 10^{3} \text { - to } 10^{5} \text {-fold less } \\
\text { responsive when seeded with brain containing } \\
\text { predominant } 4 \text {-repeat (4R) tau aggregates. }\end{array}$} & \multirow[b]{2}{*}[60]{} \\
\hline Brain and CSF & $\begin{array}{c}7 \text { cases: PSP, } 4 \text { cases: CBD, } 3 \text { cases: } \\
\text { FTDP-17 }\end{array}$ & & \\
\hline Brains & 16 cases: $\mathrm{AD}$ & $\begin{array}{l}\text { AD RT-QuIC detected seeding activity in AD brains } \\
\text { at dilutions as extreme as } 10^{7}-10^{10} \text {-fold but was } \\
10^{2}-10^{6} \text {-fold less responsive when seeded with brain } \\
\text { from most cases of other types of tauopathy }\end{array}$ & {$[61]$} \\
\hline Brains & $\begin{array}{c}11 \text { cases: AD, } 4 \text { cases: PiD, } 3 \text { cases: PSP, } \\
2 \text { cases: FTLD } \\
2 \text { cases: control subjects }\end{array}$ & $\begin{array}{l}\text { Using full-length recombinant tau substrates to } \\
\text { detect tau seeding activity in AD and other human } \\
\text { tauopathies, it will contribute to the further } \\
\text { development of early } \\
\text { detection of AD and other tauopathies }\end{array}$ & {$[62]$} \\
\hline Brains & $\begin{array}{l}8 \text { cases: } 3 R \text { Tau } \\
13 \text { cases: 3R/4R Tau } \\
13 \text { cases: } 4 \mathrm{R} \text { Tau }\end{array}$ & $\begin{array}{c}\text { K12 RT-QuIC assay allows the ultrasensitive } \\
\text { detection and discrimination of both 3R and 3R/4R } \\
\text { types of pathological tau using a single tau } \\
\text { substrate (K12CFh) }\end{array}$ & {$[63]$} \\
\hline Brain and CSF & $\begin{array}{c}\text { + } 4 \mathrm{R} \text { tau pathology included } 16 \text { cases: } \\
\text { PSP, } 9 \text { cases: CBD, } 3 \text { cases: FTDP- } 17 \\
\text { MAPT with the P301L } \\
\text { mutation, } 5 \text { cases: FTDP17 MAPT with } \\
\text { the N279K mutation and IVS10 + 3G > } \\
\text { A mutation, and 3R } \\
\text { predominant } 4 \mathrm{R} \text { tau deposition. } \\
\text { + 3R/4R tau pathology from } 6 \text { sporadic } \\
\text { AD, } 3 \text { cases: familial AD, } 3 \text { cases: } \\
\text { control subjects, and } 3 \text { cases: PART. } \\
\text { + 3R Tau from } 8 \text { cases PiD }\end{array}$ & $\begin{array}{l}\text { Developed 4R RT-QuIC for the 4-repeat (4R) tau } \\
\text { aggregates of PSP, CBD, and other diseases with } \\
4 \text { R tauopathy. } \\
\text { The assay detected seeds in } 10^{6}-10^{9} \text {-fold dilutions of } \\
\text { 4R tauopathy brain tissue but was orders of } \\
\text { magnitude less responsive to brain with other types } \\
\text { of tauopathy, such as from AD. }\end{array}$ & [64] \\
\hline
\end{tabular}

The main success of tau RT-QuIC assay based on the seeded polymerization is that it can detect and distinguish PiD from other tauopathies, neurological diseases, and healthy controls. This method could detect the tau of seeding activity in $2 \mu \mathrm{L}$ aliquots of PiD brain dilutions down to $10^{-7}-10^{-9}$; PiD seeding activities were 100 -fold higher in the frontal and temporal lobes than in the cerebellar cortex [60].

Further developments in tau assay have resulted from the advent of AD RT-QuIC, which is the first RT-QuIC 3R/4R tau test to detect tau fibers in AD and chronic traumatic encephalopathy (CTE) from brain tissue, known as AD RT-QuIC [61]. The method can detect as little as $16 \mathrm{fg}$ of pure synthetic tau fibrils. It has been shown that the tau seeding of AD and CTE are significantly different from PiD as well as different types of tau diseases such as those with $4 \mathrm{R}$ tau aggregation [61].

In the latest study, a group of a tau RT-QuIC for 4R tauopathies have been developed, specifically PSP, CBD, and FTDP-17 MAPT. This assay could detect disease-associated subtypes of $4 \mathrm{R}$ tau seeds as indicated by differences in their conformational templating of the fibrillar tau products of 4R RT-QuIC. Moreover, this study showed that the tau RT-QuIC assay can detect tau seeding activity in CSF collected from living patients. 4R RT-QuIC can detect 4R seeds in the brain tissue with up to $10^{3}-10^{6}$-fold sensitivity. $4 \mathrm{R}$ RT-QuIC analysis of postmortem CSF of the PSP and CBD CSFs each had sensitivities of $100 \%$, while $0 / 7$-unaffected controls were positive, giving a diagnostic specificity of $100 \%$. However, 4R RT-QuIC analysis of CSF had $69 \%$ and $50 \%$ of positive reactions for PSP and CBD/CBS, respectively [64]. 
Although only a short development, tau RT-QuIC has also had considerable success in diagnosing different types of taupathies with high sensitivity and specificity (Table 3).

\section{Conclusions}

Over the last 10 years, the RT-QuIC assay has gained significant attention among the available laboratory aids for the clinical diagnosis of neurodegenerative disorders. Although there are still certain limitations, RT-QuIC has become the most effective tool for the in vivo diagnosis of not only prion diseases but also synucleinopathies and tauopathies. Moreover, the advances in RT-QuIC also help direct valuable research for the early diagnosis and treatment of most of these devastating disorders.

Author Contributions: Conceptualization, K.S. and T.Đ. writing—original draft preparation, T.Đ.; writing-review and editing, K.S.; funding acquisition, K.S. All authors have read and agreed to the published version of the manuscript.

Funding: This study was financially supported by grants for scientific research from the Ministry of Health, Labour and Welfare of Japan (KSat: No. 14507303); the Research Committee of Prion Disease and Slow Virus Infection; Research on Policy Planning and Evaluation for Rare and Intractable Diseases; Health and Labour Sciences Research Grants; the Research Committee of Surveillance and Infection Control of Prion Disease; and the Japan Agency for Medical Research and Development (AMED) (grant number No. 18ek0109362h0001) and the Mitsubishi Foundation / Research Grants in the Natural Sciences.

Institutional Review Board Statement: Not applicable.

Informed Consent Statement: Not applicable.

Data Availability Statement: No new data were created or analyzed in this study. Data sharing is not applicable to this article.

Acknowledgments: We are grateful to the Japan Prion Disease Surveillance Committee.

Conflicts of Interest: The authors declare no conflict of interest.

\section{Abbreviations}

Pick disease: PiD; Chronic traumatic encephalopathy: CTE; Progressive supranuclear palsy: PSP; Corticobasal degeneration: CBD; Frontotemporal lobar degeneration: FTLD; Frontotemporal dementia with parkinsonism linked to chromosome 17 (FTDP-17); Progressive supranuclear palsy: PSP; FG: First generation; SG: Second-generation; iRBD: Isolate REM sleep behavior disorder; PAF: Pure autonomic failure.

\section{References}

1. Volpicelli-Daley, L.; Brundin, P. Prion-like propagation of pathology in Parkinson disease. Handb. Clin. Neurol. 2018, 153, 321-335.

2. Dartigues, J.F. Alzheimer's disease: A global challenge for the 21st century. Lancet Neurol. 2009, 8, 1082-1083. [CrossRef]

3. Holtzman, D.M.; Morris, J.C.; Goate, A. Alzheimer's disease: The challenge of the second century. Sci. Transl. Med. 2011, 3, 77sr71. [CrossRef] [PubMed]

4. Dementia. Available online: https://www.who.int/en/news-room/fact-sheets/detail/dementia (accessed on 21 September 2020).

5. 2020 Alzheimer's disease facts and figures. Alzheimers Dement. 2020, 16, 391-460. [CrossRef]

6. Walker, L.C. Prion-like mechanisms in Alzheimer disease. Handb. Clin. Neurol. 2018, 153, 303-319. [PubMed]

7. Caughey, B.; Lansbury, P.T. Protofibrils, pores, fibrils, and neurodegeneration: Separating the responsible protein aggregates from the innocent bystanders. Annu. Rev. Neurosci. 2003, 26, 267-298. [CrossRef] [PubMed]

8. Wilham, J.M.; Orrú, C.D.; Bessen, R.A.; Atarashi, R.; Sano, K.; Race, B.; Meade-White, K.D.; Taubner, L.M.; Timmes, A.; Caughey, B. Rapid end-point quantitation of prion seeding activity with sensitivity comparable to bioassays. PLoS Pathog. 2010, 6, e1001217. [CrossRef]

9. Atarashi, R.; Satoh, K.; Sano, K.; Fuse, T.; Yamaguchi, N.; Ishibashi, D.; Matsubara, T.; Nakagaki, T.; Yamanaka, H.; Shirabe, S. Ultrasensitive human prion detection in cerebrospinal fluid by real-time quaking-induced conversion. Nat. Med. 2011, 17, 175-178. [CrossRef] 
10. Mori, T.; Atarashi, R.; Furukawa, K.; Takatsuki, H.; Satoh, K.; Sano, K.; Nakagaki, T.; Ishibashi, D.; Ichimiya, K.; Nishida, N. A direct assessment of human prion adhered to steel wire using realtime quaking-induced conversion. Sci. Rep. 2016, 6, 24993. [CrossRef]

11. Collinge, J.; Palmer, M.S.; Sidle, K.C.; Hill, A.F.; Gowland, I.; Meads, J.; Asante, E.; Bradley, R.; Doey, L.J.; Lantos, P.L. Unaltered susceptibility to BSE in transgenic mice expressing human prion protein. Nature 1995, 378, 779-783. [CrossRef]

12. Hill, A.F.; Desbruslais, M.; Joiner, S.; Sidle, K.C.; Gowland, I.; Collinge, J.; Doey, L.J.; Lantos, P. The same prion strain causes vCJD and BSE. Nature 1997, 389, 448-450. [CrossRef] [PubMed]

13. Taguchi, Y.; Mohri, S.; Ironside, J.W.; Muramoto, T.; Kitamoto, T. Humanized knock-in mice expressing chimeric prion protein showed varied susceptibility to different human prions. Am. J. Pathol. 2003, 163, 2585-2593. [CrossRef]

14. Telling, G.C.; Scott, M.; Hsiao, K.K.; Foster, D.; Yang, S.L.; Torchia, M.; Sidle, K.C.; Collinge, J.; DeArmond, S.J.; Prusiner, S.B. Transmission of Creutzfeldt-Jakob disease from humans to transgenic mice expressing chimeric human-mouse prion protein. Proc. Natl. Acad. Sci. USA 1994, 91, 9936-9940. [CrossRef]

15. Saborio, G.P.; Permanne, B.; Soto, C. Sensitive detection of pathological prion protein by cyclic amplification of protein misfolding. Nature 2001, 411, 810-813. [CrossRef] [PubMed]

16. Soto, C.; Saborio, G.P.; Anderes, L. Cyclic amplification of protein misfolding: Application to prion-related disorders and beyond. Trends Neurosci. 2002, 25, 390-394. [CrossRef]

17. Yokoyama, T.; Takeuchi, A.; Yamamoto, M.; Kitamoto, T.; Ironside, J.W.; Morita, M. Heparin enhances the cell-protein misfolding cyclic amplification efficiency of variant Creutzfeldt-Jakob disease. Neurosci. Lett. 2011, 498, 119-123. [CrossRef] [PubMed]

18. Imamura, M.; Tabeta, N.; Kato, N.; Matsuura, Y.; Iwamaru, Y.; Yokoyama, T.; Murayama, Y. Heparan sulfate and heparin promote faithful prion replication in vitro by binding to normal and abnormal prion proteins in protein misfolding cyclic amplification. $J$. Biol. Chem. 2016, 291, 26478-26486. [CrossRef] [PubMed]

19. Rubenstein, R.; Chang, B. Re-assessment of PrP $\mathrm{P}^{\mathrm{Sc}}$ distribution in sporadic and variant CJD. PLoS ONE 2013, 8, e66352. [CrossRef]

20. Bougard, D.; Brandel, J.-P.; Bélondrade, M.; Béringue, V.; Segarra, C.; Fleury, H.; Laplanche, J.-L.; Mayran, C.; Nicot, S.; Green, A.; et al. Detection of prions in the plasma of presymptomatic and symptomatic patients with variant Creutzfeldt-Jakob disease. Sci. Transl. Med. 2016, 8, 370. [CrossRef]

21. Moda, F.; Gambetti, P.; Notari, S.; Concha-Marambio, L.; Catania, M.; Park, K.W.; Maderna, E.; Suardi, S.; Haïk, S.; Soto, C.; et al . Prions in the urine of patients with variant Creutzfeldt-Jakob disease. N. Engl. J. Med. 2014, 371, 530-539. [CrossRef] [PubMed]

22. Wang, F.; Wang, X.; Yuan, C.-G.; Ma, J. Generating a Prion with Bacterially xpressed Recombinant Prion Protein. Science 2010. [CrossRef]

23. Peden, A.H.; McGuire, L.I.; Appleford, N.E.J.; Mallinson, G.; Wilham, J.M.; Orrú, C.D.; Caughey, B.; Ironside, J.W.; Knight, R.S.; Will, R.G.; et al. Sensitive and specific detection of sporadic Creutzfeldt-Jakob disease brain prion protein using real-time quaking induced conversion. J. Gen. Virol. 2012, 93, 438-449. [CrossRef] [PubMed]

24. Foutz, A.; Appleby, B.S.; Hamlin, C.; Liu, X.; Yang, S.; Cohen, Y.; Chen, W.; Blevins, J.; Fausett, C.; Wang, H.; et al. Diagnostic and prognostic value of human prion detection in cerebrospinal fluid. Ann. Neurol. 2017, 81, 79-92. [CrossRef]

25. Cramm, M.; Schmitz, M.; Karch, A.; Mitrova, E.; Kuhn, F.; Schroeder, B.; Raeber, A.; Varges, D.; Kim, Y.S.; Satoh, K.; et al. Stability and Reproducibility underscore utility of RT-QuIC for diagnosis of creutzfeldt-jakob Disease. Mol. Neurobiol. 2016, 53, 1896-1904. [CrossRef] [PubMed]

26. Orrú, C.D.; Wilham, J.M.; Raymond, L.D.; Kuhn, F.; Schroeder, B.; Raeber, A.J.; Caughey, B. Prion disease blood test using immunoprecipitation and improved quaking-induced conversion. mBio 2011, 2, e00078-11. [CrossRef] [PubMed]

27. Orrú, C.D.; Groveman, B.R.; Hughson, A.G.; Zanusso, G.; Coulthart, M.B.; Caughey, B. Rapid and sensitive RT-QuIC detection of human Creutzfeldt-Jakob disease using cerebrospinal fluid. MBio 2015, 6, e02451-14. [CrossRef] [PubMed]

28. Bongianni, M.; Orrù, C.; Groveman, B.R.; Sacchetto, L.; Fiorini, M.; Tonoli, G.; Triva, G.; Capaldi, S.; Testi, S.; Ferrari, S.; et al. Diagnosis of human prion disease using real-time quaking-induced conversion testing of olfactory mucosa and cerebrospinal fluid samples. JAMA Neurol 2017, 74, 155-162. [CrossRef] [PubMed]

29. Groveman, B.R.; Orrú, C.D.; Hughson, A.G.; Bongianni, M.; Fiorini, M.; Imperiale, D.; Ladogana, A.; Pocchiari, M.; Zanusso, G.; Caughey, B. Extended and direct evaluation of RT-QuIC assays for Creutzfeldt- Jakob disease diagnosis. Ann. Clin. Transl. Neurol. 2016, 4, 139-144. [CrossRef]

30. Franceschini, A.; Baiardi, S.; Hughson, A.G.; McKenzie, N.; Moda, F.; Rossi, M.; Capellari, S.; Green, A.; Parchi, P. High diagnostic value of second generation CSF RT-QuIC across the wide spectrum of CJD prions. Sci. Rep. 2017, 7, 10655. [CrossRef] [PubMed]

31. Ladogana, A.; Sanchez-Juan, P.; Mitrová, E.; Green, A.; Cuadrado-Corrales, N.; Sánchez-Valle, R.; Koscova, S.; Aguzzi, A.; Sklaviadis, T.; Zerr, I.; et al. Cerebrospinal fluid biomarkers in human genetic transmissible spongiform encephalopathies. $J$. Neurol. 2009, 256, 1620-1628. [CrossRef]

32. Sano, K.; Satoh, K.; Atarashi, R.; Takashima, H.; Iwasaki, Y.; Yoshida, M.; Sanjo, N.; Murai, H.; Mizusawa, H.; Nishida, N. Early detection of abnormal prion protein in genetic human prion diseases now possible using real-time QuIC assay. PLoS ONE 2013, 8, e54915. [CrossRef]

33. McGuire, L.I.; Peden, A.H.; Orrú, C.D.; Wilham, J.M.; Appleford, N.E.; Mallinson, G.; Andrews, M.; Head, M.W.; Caughey, B.; Green, A.J.E.; et al. RT-QuIC analysis of cerebrospinal fluid in sporadic Creutzfeldt-Jakob disease. Ann. Neurol. 2012, 72, 278-285. [CrossRef] 
34. Lattanzio, F.; Abu-Rumeileh, S.; Franceschini, A.; Kai, H.; Amore, G.; Poggiolini, I.; Rossi, M.; Baiardi, S.; McGuire, L.; Parchi, P.; et al. Prion-specific and surrogate CSF biomarkers in Creutzfeldt-Jakob disease: Diagnostic accuracy in relation to molecular subtypes and analysis of neuropathological correlates of p-tau and Ab42 levels. Acta Neuropathol. 2017, 133, 559-578. [CrossRef]

35. Orrú, C.D.; Bongianni, M.; Tonoli, G.; Ferrari, S.; Hughson, A.G.; Groveman, B.R.; Fiorini, M.; Pocchiari, M.; Monaco, S.; Caughey, B.; et al. A test for Creutzfeldt-Jakob disease using nasal brushings. N. Engl. J. Med. 2014, 371, 519-529. [CrossRef] [PubMed]

36. Park, J.H.; Choi, Y.G.; Lee, Y.J.; Park, S.J.; Choi, H.S.; Choi, K.C.; Choi, E.K.; Kim, Y.S. Real-time quakinginduced conversion analysis for the diagnosis of sporadic Creutzfeldt-Jakob disease in Korea. J. Clin. Neurol. 2016, 12, 101-106. [CrossRef] [PubMed]

37. Orrú, C.D.; Yuan, J.; Appleby, B.S.; Li, B.; Li, Y.; Winner, D.; Wang, Z.; Zhan, Y.A.; Rodgers, M.; Zou, W.Q.; et al. Prion seeding activity and infectivity in skin samples from patients with sporadic Creutzfeldt-Jakob disease. Sci Transl Med. 2017, 9, eaam7785. [CrossRef]

38. Orrù, C.D.; Soldau, K.; Cordano, C.; Llibre-Guerra, J.; Green, A.J.; Sanchez, H.; Groveman, B.R.; Edland, S.D.; Safar, J.G.; Lin, J.H.; et al. Prion Seeds Distribute throughout the Eyes of Sporadic Creutzfeldt-Jakob Disease Patients. mBio 2018, 9, e02095-18. [CrossRef] [PubMed]

39. Hermann, P.; Laux, M.; Glatzel, M.; Matschke, J.; Knipper, T.; Goebel, S.; Treig, J.; Schulz-Schaeffer, W.; Cramm, M.; Schmitz, M.; et al. Validation and utilization of amended diagnostic criteria in Creutzfeldt-Jakob disease surveillance. Neurology 2018, 91, e331-e338. [CrossRef] [PubMed]

40. Baiardi, S.; Redaelli, V.; Ripellino, P.; Rossi, M.; Franceschini, A.; Moggio, M.; Sola, P.; Ladogana, A.; Fociani, P.; Magherini, A.; et al. Prion-related peripheral neuropathy in sporadic Creutzfeldt-Jakob disease. J. Neurol. Neurosurg Psychiatry 2019, 90, 424-427. [CrossRef] [PubMed]

41. Satoh, K.; Fuse, T.; Nonaka, T.; Dong, T.; Takao, M.; Nakagaki, T.; Ishibashi, D.; Taguchi, Y.; Mihara, B.; Iwasaki, Y.; et al. Postmortem Quantitative Analysis of Prion Seeding Activity in the Digestive System. Molecules 2019, 24, 4601. [CrossRef] [PubMed]

42. Mammana, A.; Baiardi, S.; Rossi, M.; Franceschini, A.; Donadio, V.; Capellari, S.; Caughey, B.; Parchi, P. Detection of prions in skin punch biopsies of Creutzfeldt-Jakob disease patients. Ann. Clin. Transl. Neurol. 2020, 7, 559-564. [CrossRef]

43. Fiorini, M.; Iselle, G.; Perra, D.; Bongianni, M.; Capaldi, S.; Sacchetto, L.; Ferrari, S.; Mombello, A.; Vascellari, S.; Testi, S.; et al. High Diagnostic Accuracy of RT-QuIC Assay in a Prospective Study of Patients with Suspected sCJD. Int. J. Mol. Sci. 2020, 21, 880. [CrossRef]

44. Fairfoul, G.; McGuire, L.I.; Pal, S.; Ironside, J.W.; Neumann, J.; Christie, S.; Joachim, C.; Esiri, M.; Evetts, S.G.; Green, A.J. Alpha-synuclein RT-QuIC in the CSF of patients with alpha-synucleinopathies. Ann. Clin. Transl. Neurol. 2016, 3, 812-818. [CrossRef] [PubMed]

45. Shahnawaz, M.; Tokuda, T.; Waragai, M.; Mendez, N.; Ishii, R.; Trenkwalder, C.; Mollenhauer, B.; Soto, C. Development of a biochemical diagnosis of Parkinson disease by detection of alpha-synuclein misfolded aggregates in cerebrospinal fluid. JAMA Neurol. 2017, 74, 163-172. [CrossRef] [PubMed]

46. Sano, K.; Atarashi, R.; Satoh, K.; Ishibashi, D.; Nakagaki, T.; Iwasaki, Y.; Yoshida, M.; Murayama, S.; Mishima, K.; Nishida, N. Prion-Like Seeding of Misfolded $\alpha$-Synuclein in the Brains of Dementia with Lewy Body Patients in RT-QuIC. Mol. Neurobiol. 2018, 55, 3916-3930. [CrossRef] [PubMed]

47. Groveman, B.R.; Orrù, C.D.; Hughson, A.G.; Raymond, L.D.; Zanusso, G.; Ghetti, B.; Campbell, K.J.; Safar, J.; Galasko, D.; Caughey, B. Rapid and ultra-sensitive quantitation of disease-associated alpha-synuclein seeds in brain and cerebrospinal fluid by alphaSyn RT-QuIC. Acta Neuropathol. Commun. 2018, 6, 7. [CrossRef]

48. De Luca, C.M.D.; Elia, A.D.; Portaleone, S.M.; Cazzaniga, F.A.; Rossi, M.; Bistaffa, E.; De Cecco, E.; Narkiewicz, J.; Salzano, G.; Moda, F.; et al. Efficient RT-QuIC seeding activity for alpha-synuclein in olfactory mucosa samples of patients with Parkinson's disease and multiple system atrophy. Transl. Neurodegener. 2019, 8, 24. [CrossRef]

49. Bongianni, M.; Ladogana, A.; Capaldi, S.; Klotz, S.; Baiardi, S.; Cagnin, A.; Perra, D.; Fiorini, M.; Poleggi, A.; Zanusso, G. Alpha-Synuclein RT-QuIC assay in cerebrospinal fluid of patients with dementia with Lewy bodies. Ann. Clin. Transl. Neurol. 2019, 6, 2120-2126. [CrossRef]

50. Manne, S.; Kondru, N.; Jin, H.; Anantharam, V.; Huang, X.; Kanthasamy, A.; Kanthasamy, A.G. alpha-Synuclein real-time quaking-induced conversion in the submandibular glands of Parkinson's disease patients. Mov. Disord. 2019, 35, 268-278. [CrossRef]

51. Kang, U.J.; Boehme, A.K.; Bs, G.F.; Shahnawaz, M.; Ma, T.C.; Hutten, S.J.; Green, A.; Soto, C. Comparative study of cerebrospinal fluid alpha-synuclein seeding aggregation assays for diagnosis of Parkinson's disease. Mov. Disord. 2019, 34, 536-544. [CrossRef]

52. Van Rumund, A.; Green, A.J.E.; Fairfoul, G.; Esselink, R.A.J.; Bloem, B.R.; Verbeek, M.M. Alpha-Synuclein real-time quakinginduced conversion in the cerebrospinal fluid of uncertain cases of parkinsonism. Ann. Neurol. 2019, 85, 777-781. [CrossRef]

53. Garrido, A.; Fairfoul, G.; Tolosa, E.S.; Marti, M.J.; Green, A.; Barcelona, L.S.G. Alpha-synuclein RT-QuIC in cerebrospinal fluid of LRRK2-linked Parkinson's disease. Ann. Clin. Transl. Neurol. 2019, 6, 1024-1032. [CrossRef]

54. Rossi, M.; Candelise, N.; Baiardi, S.; Capellari, S.; Giannini, G.; Orrù, C.D.; Antelmi, E.; Mammana, A.; Hughson, A.G.; Parchi, P. Ultrasensitive RT-QuIC assay with high sensitivity and specificity for Lewy body-associated synucleinopathies. Acta Neuropathol. 2020, 140, 49-62. [CrossRef] [PubMed] 
55. Iranzo, A.; Fairfoul, G.; Na Ayudhaya, A.C.; Serradell, M.; Gelpi, E.; Vilaseca, I.; Sanchez-Valle, R.; Gaig, C.; Santamaria, J.; Tolosa, E.; et al. Detection of $\alpha$-synuclein in CSF by RT-QuIC in patients with isolated rapid-eye-movement sleep behaviour disorder: A longitudinal observational study. Lancet Neurol. 2021, 20, 203-212. [CrossRef]

56. Wang, Z.; Becker, K.; Donadio, V.; Siedlak, S.; Yuan, J.; Rezaee, M.; Incensi, A.; Kuzkina, A.; Orrú, C.D.; Tatsuoka, C.; et al. Skin $\alpha$-Synuclein Aggregation Seeding Activity as a Novel Biomarker for Parkinson Disease. JAMA Neurol. 2020, 78, 1-11. [CrossRef] [PubMed]

57. Manne, S.; Kondru, N.; Jin, H.; Serrano, G.E.; Anantharam, V.; Kanthasamy, A.; Adler, C.H.; Beach, T.G.; Kanthasamy, A.G. Blinded RT-QuIC Analysis of $\alpha$-Synuclein Biomarker in Skin Tissue From Parkinson's Disease Patients. Mov. Disord. 2020, 35, 2230-2239. [CrossRef]

58. Salvadores, N.; Shahnawaz, M.; Scarpini, E.; Tagliavini, F.; Soto, C. Detection of misfolded A $\beta$ oligomers for sensitive biochemical diagnosis of Alzheimer's disease. Cell Rep. 2014, 7, 261-268. [CrossRef]

59. Jack, C.R., Jr.; Bennett, D.A.; Blennow, K.; Carrillo, M.C.; Dunn, B.; Haeberlein, S.B.; Holtzman, D.M.; Jagust, W.; Jessen, F.; Sperling, R.; et al. NIA-AA Research Framework: Toward a biological definition of Alzheimer's disease. Alzheimers Dement. 2018, 14, 535-562. [CrossRef]

60. Saijo, E.; Ghetti, B.; Zanusso, G.; Oblak, A.; Furman, J.L.; Diamond, M.I.; Kraus, A.; Caughey, B. Ultrasensitive and selective detection of 3-repeat tau seeding activity in Pick disease brain and cerebrospinal fluid. Acta Neuropathol. 2017, 133, 751-765. [CrossRef]

61. Kraus, A.; Saijo, E.; Metrick, M.A., II; Newell, K.; Sigurdson, C.J.; Zanusso, G.; Ghetti, B.; Caughey, B. Seeding selectivity and ultrasensitive detection of tau aggregate conformers of Alzheimer disease. Acta Neuropathol. 2019, 137, 585-598. [CrossRef]

62. Tennanta, J.M.; Hendersona, D.M.; Wisniewskib, T.M.; Hoovera, E.A. RT-QuIC detection of tauopathies using full-length tau substrates. Prion 2020, 14, 249-256. [CrossRef] [PubMed]

63. Metrick, M.A., II; Ferreira, N.D.C.; Saijo, E.; Kraus, A.; Newell, K.; Zanusso, G.; Vendruscolo, M.; Ghetti, B.; Caughey, B. A single ultrasensitive assay for detection and discrimination of tau aggregates of Alzheimer and Pick diseases. Acta Neuropathol. Commun. 2020, 8, 22. [CrossRef] [PubMed]

64. Saijo, E.; Metrick, M.A., II; Koga, S.; Parchi, P.; Litvan, I.; Spina, S.; Boxer, A.; Rojas, J.C.; Galasko, D.; Caughey, B.; et al. 4-Repeat tau seeds and templating subtypes as brain and CSF biomarkers of frontotemporal lobar degeneration. Acta Neuropathol. 2020, 139, 63-77. [CrossRef] [PubMed] 